\title{
The cult of Carr
}

\section{Emily Carr: New Perspectives}

Curators Charles Hill, Ian Thom and

Johanne Lamoureux

National Gallery of Canada

Until Sept. 4, 2006

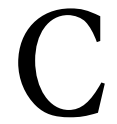

anadians embrace Emily Carr (I87I-I945) for her vision of our country, her documentation and, later, interpretation of the culture that preceded us, and her exploration of the spiritual link through nature. This vision is powerful. This is exhibit worthy.

And now, there is a new exhibition celebrating, er, those exhibits. Or at least a few of them. It seems an odd approach, but perhaps inevitable given how heavily Carr territory has been trod upon. She is the most written about artist in Canada with more than go texts (and 4 more due this year). Likewise, she's had the most major retrospectives: 4 including 2 at the National Gallery of Canada in the past $\mathrm{I} 6$ years. Unquestionably a box-office hit, Carr has joined the highly questionable cult of celebrity, where no detail is too inconsequential. And there is plenty to hash over: her contradictions, her hyperbole and her appropriation of Aboriginal iconography, and so on, seemingly ad infinitum. The minutia of her life, the endless speculation about her motives and state of mind are seemingly as important, if not more so, as her works of art.

And so we have the National Gallery of Canada and Vancouver Art Gallery copresenting Emily Carr: New Perspectives (or simply Emily, as the gallery dubs it). Vancouver curator, Ian Thom, struggled to find a new way to present Carr to mark the gallery's $75^{\text {th }}$ anniversary. It took a think-tank of curators and scholars to come up with the idea of exploring the "variety of paradigms within the artist's exhibition history" (p. 8). Thus, the exhibit focuses on 3 pivotal places: the 1927 group exhibit that marked her emergence on the national stage, the first historical interpretation of her work in 1945 , and a third component exploring her social and political aspects and reflecting the artist herself, partially based on the 1990 National Gallery retrospective. (So apparently we're seeing a retrospective of a I9go retrospective.)

The promotional poster epitomizes this approach. Rather than an image of her art, we have Carr's face, not at the prime of her artistic career, but at age $2 \mathrm{I}$

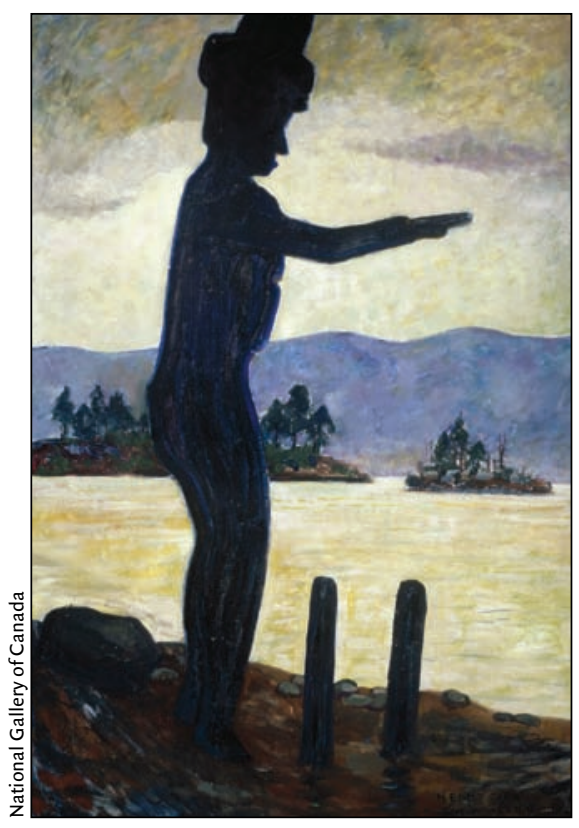

Emily Carr, The Welcome Man (1913). Oil on cardboard. $95.3 \times 64.8 \mathrm{~cm}$. National Gallery of Canada, Ottawa. Gift of Bryan Adams, Vancouver, 2000. or 22 when she was studying art. Why this image? Why not her art? Presumably because Carr herself is now more important, and this particular photo feeds the legend; on top of everything else, she is now beautiful and young.

And so, it seems that Emily Carr: New Perspectives offers new perspectives of the artist herself, and, almost incidentally, her art. Although it is the latter that makes the exhibit satisfyingly worthwhile: more than 200 objects (I50 by Carr) including paintings, drawings, watercolours, caricatures, ceramics, sculptures, hooked rugs and photographs.

The exhibit begins with the partial restaging of the exhibition West Coast Art: Native and Modern, which opened in I927 at Ottawa's national gallery. For the first time, Carr, then 55 years old, joined her contemporaries including A.Y. Jackson, Edwin Holgate (who also installed the exhibit) and Lawren Harris. Along with their paintings is a display of Aboriginal art as well as artistic interpretations of Aboriginal motifs, most charmingly Florence Wyle's cast iron Owl Bookends (1927). This partial remounting of the I927 exhibit differs significantly from the original exhibit in that information is provided about the Aboriginal works (thus moving them from ethnography to art) and the historical context. Following the federal banning of the Potlatch (I884), when totem poles were traditionally erected, many artifacts were seized or sold. In 1907 Carr began documenting and painting what in fact was a dying culture. Through the 3I paintings Carr exhibited in 1927 , she emerged as an interpreter, a mediator for First Nations, and the exhibit's star.

All Carr's I2 works in this remounted exhibit are from her early career 
(I9I2-I3) and feature picturesque views of village scenes including Graveyard Entrance, Campbell River (I9I2) and Skidegate (I9I2). Also featured are her pottery and the graphically satisfying Killer Whale Rug (I927). She signed all these, as well as her illustration for the I927 exhibit's catalogue with her Aboriginal nickname, Klee Wyck - "she who laughs" - causing confusion as to her identity in the context of the exhibit.

The 1927 exhibit had a powerful influence on Carr, who declared: "[A.Y. Jackson's] Indian pictures have something mine lack - rhythm, poetry. Mine are so downright ... I worked for history and cold fact. Next time I paint Indians I'm going off on a tangent tear." ${ }^{\text {I }}$ (p. I57). Carr also met Lawren Harris who encouraged her to adopt a more subjective, emotive approach. On a practical level, Carr sold enough works to pay for a trip back to the Northern BC coast in the summer of 1928 and so resumed painting after a I5-year hiatus, during which she made her living by renting apartments, raising dogs and making Haida-themed pottery and rugs.

Fast forward now to I945, the year of her death. Her executor, Lawren Harris, honoured her oeuvre (collective works) in Emily Carr: Modernism Remembered, at the Art Gallery of Toronto (later of Ontario). Inspired by that exhibition, the rooms in the current exhibit feature some of her finest works (1920-42) and evoke her 2 dominant concerns: primitivism and spirituality, beautifully expressed in Indian Church (I929), where the church bridges death (cemetery) and life (forest).

This portion of the exhibit also partly documents her artistic progression. After studying in France (I9IO-II), Carr adopted Modernist concerns and the primary-colour palette of fauvism. Following the I927 exhibit, she began to transcend ethnographic concerns through a visual language that was as forceful as the art she was depicting. Narrowing her focal point to single or small groups of totem poles, she used compositional techniques to engage the viewer in works such as Silhouette No. 2 (1930) - a modernist reworking of The Welcome Man (I9I3) — and Big Raven (I93I) - a dramatic simplification and amplification of Cumshewa (I9I2).

In the early i93os, Harris encour-

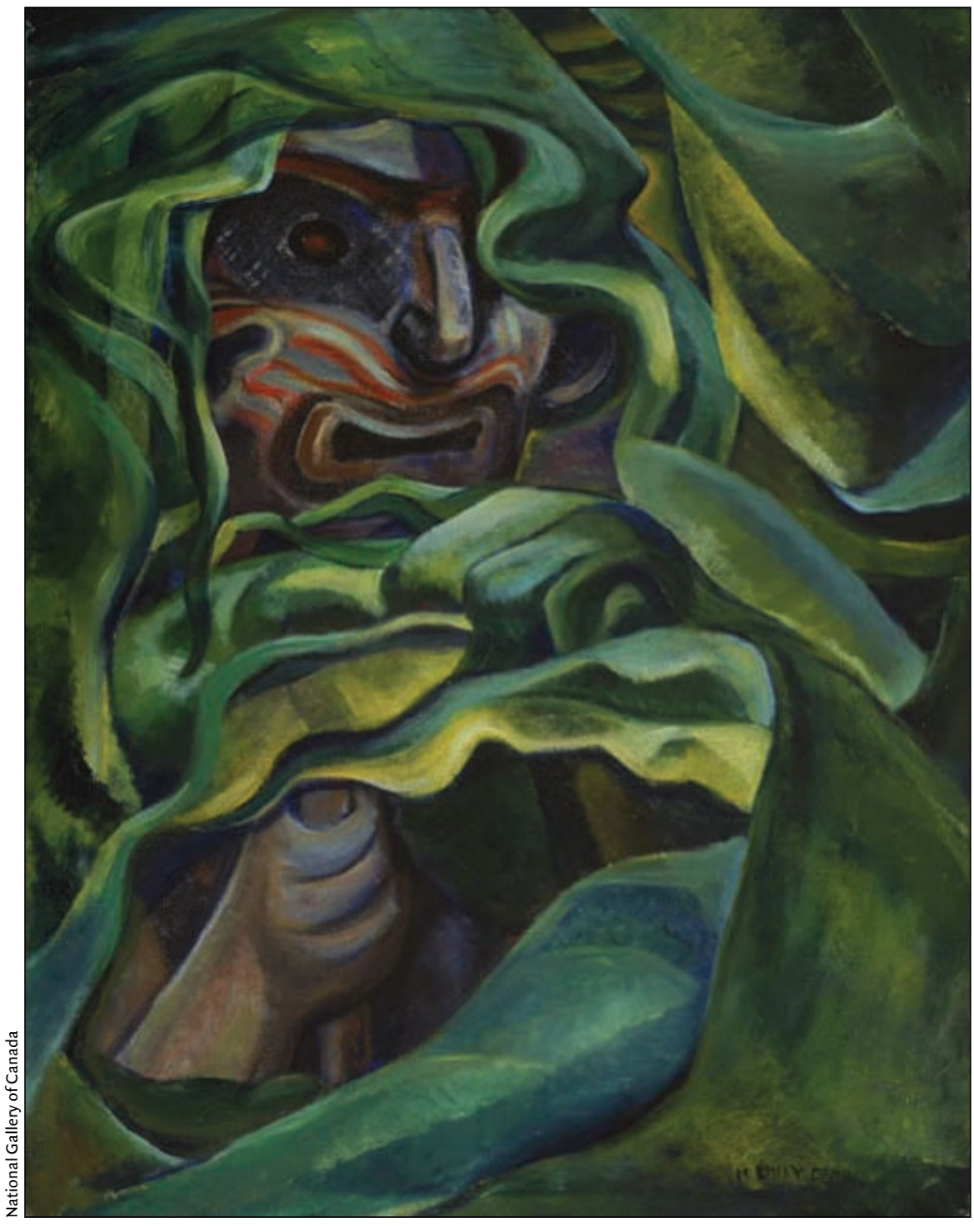

Emily Carr, Strangled by Growth (1931). Oil on canvas. $64 \times 48.6 \mathrm{~cm}$. Vancouver Art Gallery Emily Carr Trust.

aged Carr to leave totems behind, writing that they were a work of art in their own right and very difficult to use in another form of art. Carr was ready for a change, remarking in 1929 that: "The Indians had sold most of their best poles.... The recent carvings were superficial, meaningless; the Indian had lost faith in his totem." (p. I58).

We see in this second section and parts of the third, multi-faceted section, Carr's dual approach to nature. Anthropomorphism is evident in Grey (1929-30) and Happiness (1939). She also used animism to find spirituality in nature. Thus we see the sweeping brushstrokes and undulating lines of
Fir Tree and Sky (1935-36).

The opening room of the third section highlights her evolving vision of Aboriginal icons and villages, mostly from works in I930. In Strangled by Growth (I93I) she partly hides the totems amidst vegetation to accentuate its impenetrability, both cultural and natural. The exhibit points out that sometimes Carr got facts wrong: The Crying Totem (1928) is misnamed (the chief had pendulous eyes, he wasn't crying) and Guyasdoms D'Sonoqua (c. I930) isn't an abandoned village, its residents were all out working in a canning plant.

Another room is devoted to her interpretation of the industrialization of na- 
ture, primarily through logging, which she, like many others, believed was ecologically sustainable. Inspired by a 1933 trip to Chicago through the "skies and space" of the prairies, she began painting clearings and skies around her native Victoria, imbuing in them her personal spiritual vision. Hence it is not the earth but the pulsating blue sky and thick swirling clouds that dominate Scorned as Timber, Beloved of the Sky (I935) and Above the Gravel Pit (I937). Under the weight of these huge skies, the earth is frail, failing. After suffering a heart attack in 1937, Carr began writing stories (in I942 she received the Governor General's Literary Award [non-fiction] for her first book, Klee Wyck), and though forced to abandon her trips into the hinterland, she continued painting around Victoria.

Another section, documenting the use of Haida iconography for tourism, features her ethnographic paintings of villages and portraits of Aboriginal people she befriended, and also features a rug, platter and pincushion. It's easy to be critical of her appropriation of this iconography for financial gain, but no one was more critical than herself; she wrote that she hated herself for this exploitation.

The final room of the exhibit explores how she saw herself and how others saw her through photographs, paintings and an impressive display of the books, 6 of which she authored. This room documents the clichés: Carr as a feminist ahead of her time, as a pet lover, friend and tireless letter writer, impassioned artist and loner.

Most charming are her illustrated journals that seem to be an attempt to claim herself, as an explorer, tourist and independent woman. The amusing, frequently self-deprecating caricatures (usually in watercolour) and frequently misspelled text are reproduced and bound for individual viewings (but unfortunately, not for sale). They recount the adventures of our hapless heroine as she faces challenges both great and small, including the hilarious Sister and I from Victoria to London Memoirs of Ods [sic] and Ends (I9Io), after which she abandoned this genre. Although the travel journals are wickedly funny, they also betray how stressful she found city life and the drive to be a recognized artist. She was hospitalized during both of her trips to Europe. After a physical and nervous breakdown in London, she was diagnosed with hysteria and spent I8 months in a sanatorium. She fell ill with similar symptoms while in France and was hospitalized for several months.

Appropriation of voice, early influ-

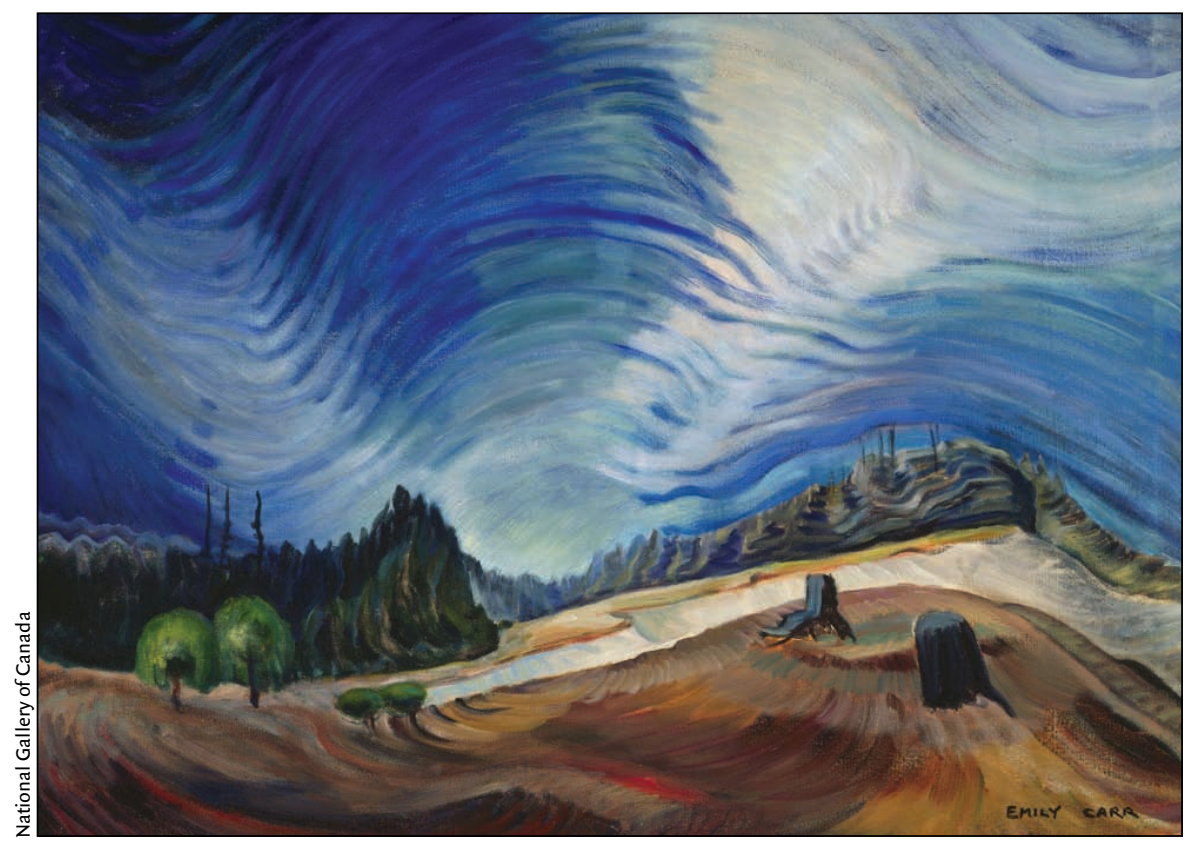

Emily Carr, Above the Gravel Pit (1937). Oil on canvas. $77.2 \times 102.3 \mathrm{~cm}$. Vancouver Art Gallery Emily Carr Trust. ences and other aspects of her character, if not her art per se, are more fully explored in the exhibit catalogue. Some of the essays on various influential periods in her life (e.g., Alaska, France) offer a chronology that is missing in the show. Oddly, however, the chronology of the show itself is not included; the art images are interspersed in the text rather than altogether, leaving one with the impression that the essays are more important, more illuminating than this exhibit's art.

Repeatedly in the exhibit and catalogue, much is made - despite the 90 books - of the "mystery" of Carr, as if there has to be some explanation for the inherent humanness of her contradictions of character and action, her unreliable (or revisionist) memory, for the fact that her writings are more literary than historical (creative nonfiction in today's lexicon). She purported to be interested in ethnography, yet lacked formal training and made errors. She is criticized for being aware of the Aboriginal plight, yet not acting (is that the artist's task?). It makes one wonder whether we are guilty of that quintessential Canadian trait of being unable to simply enjoy the success of one of our own. Perhaps the problem is not that there isn't enough information about her, but that there is too much; we get mired in the minutia of her life, the endless speculation about her motives, which, in the end, are muddied by historical backwash or lost altogether. If she is guilty of appropriating the $\mathrm{Ab}$ original persona, her critics are guilty of appropriating her persona and assuming to know who she was, rather than letting her evocative art speak for her.

\section{Barbara Sibbald CMAJ}

\section{REFERENCE}

I. Hill C, et al. Emily Carr: new perspective on a Canadian Icon [exhibition catalogue]. Ottawa: $\mathrm{Na}-$ tional Gallery of Canada; 2006.

\section{Exhibition itinerary:}

Vancouver Art Gallery, Vancouver, BC, Oct. 7, 2006 - Jan. 7, 2007; Art Gallery of Ontario, Toronto, Ont., Feb. 24- May 20, 2007; Montreal Museum of Fine Arts, Montréal, Que., June 21 - Sept. 23, 2007; Glenbow Museum, Calgary, Alta., Oct. 25, 2007-Jan. 26, 2008. 